\title{
Determining the Effectiveness of ALMP on Youth in Serbia ${ }^{2}$
}

\author{
Article history \\ Received: 10. June 2013 \\ Sent for revision: 12 . July 2013 \\ Received in revised form: 11 . September 2013 \\ Accepted: 15. September 2013 \\ Available online: 06. November 2013
}

\begin{abstract}
The focus of research in this paper is on analysing the effectiveness of the active labour market policies in one of the largest vulnerable groups in Serbian labour market - youth population. By means the nearest neighbour matched pair design applied on the youth population cohort at the labour market, the aim was to determine what policies bring about the most gains in comparison to their absence. Moreover by using PSM methodology there was performed a micro-evaluation of several different types of ALMP used in Serbia with a goal of obtaining precise information on the difference in effects among such policies. Main results show that labour market policies for youth population are at least as effective as for general population, leading to around 28\% higher chance of a person participating in the treatment to remain employed 6 months later as compared to non-participants. Employment and start-up incentives and apprenticeship training show best results, but surprisingly public works have shown nearly no effects, with an expected net loss in a long term.
\end{abstract}

Keywords: ALMP, Matched pair design, Serbian labour market

\section{Određivanje efektivnost aktivnih mera na tržištu rada kod mladih u Srbiji}

Apstrakt: Fokus istraživanja u ovom radu je stavljen na analizu efikasnosti aktivnih politika tržišta rada na jednoj od najvećih ranjivih grupa na tržištu rada Srbije - populaciji mladih. Primenom uparivanja putem metoda najbližeg

\footnotetext{
${ }^{1}$ Economics Institute, jovan.zubovic@ecinst.org.rs

2 The paper presents the results of a study conducted as part of the projects 179001 , 179015 funded by the Ministry of Education, Science and Technological Development of the Republic of Serbia.
} 
suseda na kohorti mladih na tržištu rada, cilj je bio da se utvrdi koje politike donose najveću korist u odnosu na njihovo odsustvo. Takođe je pomoću PSM metodologije je izvršena mikro-procena nekoliko različitih vrsta mera koje se koriste u Srbiji, sa ciljem da se dobiju precizne informacije o efektima takve politike. Glavni rezultati pokazuju da je politika tržišta rada za mlade podjednako efikasna kao i kod ostalih nezaposlenih, sa oko 28 \% većom šansom da lice koje učestvuje u meri ostane zaposleno 6 meseci nakon izlaska iz mere nego kod onih koji nisu učestvovali u merama. Subvencije za zapošljavanje $i$ osnivanje firmi, kao i obuka na poslu pokazuju najbolje rezultate, a iznenađujuće je da su javni radovi pokazali skoro nikakve efekte, uz očekivani neto gubitak u dugom roku.

KIjučne reči: ALMP, metod odgovarajućih parova, tržište rada u Srbiji

\section{Introduction}

During the last half of the century many different types of state interventions in labour markets have been introduced worldwide. Some of them have influenced demand side in the labour markets, while the others had a goal of improving the offer side. What was common to all of them was that the emphasis on them had been put in the periods of crisis. The latest crisis which is influencing all labour markets in the world has shown to be long lasting. Therefore its impact is very strong and there is a need for renewed analysis of the effectiveness of different types of government interventions aiming to reduce unemployment.

Unlike during the previous crises, most of the countries with rising unemployment rate today are facing the problem of high debt as well. For that reason there is an increased pressure on policy makers to reduce public spending, which is the source of financing labour market policies. For that reason it is becoming even more important to effectively select which policies to finance, and which of them will bring most sustainable results. As Sredojević, Jeločnik and Subić (2011) have noted, there is a need to improve the system of labour market policies, since the former system was not delivering the expected results.

In Serbia, the problem of growing debt, which has grown from 29.2\% in 2008 to $62.2 \%$ in 2013 (National Bank of Serbia, 2013) has influenced the Ministries responsible for Labour issues to reduce financing of active labour market policies (ALMP). In that period government spending on ALMP in Serbia equalled only $0.11 \%$ of GDP in 2008 , substantially lower than $0.76 \%$ which is an average in EU27. Increase of the expenditure to $0.17 \%$ in 2011 generated positive results measured by econometric tools (Zubović, Subić 2011; Eunes 2011 ), but it has been followed by significant decrease to $0.07 \%$ in 2012 . Dur- 
ing the same period the unemployment rate in Serbia has grown from $13.6 \%$ to $23.9 \%$, with the youth unemployment rate skyrocketing at $51.0 \%$ (Statistical Office of Serbia, 2013).

Given the fact that there is a trend in reduction of financing of ALMP, and that youth unemployment is growing faster than general unemployment, the goal of this paper is to determine which specific policies have been most effective on youth in order to provide help to policy makers to redistribute diminishing funds. Similar research has been previously conducted in Croatia (Matkovic, Babic \& Vuga, 2012) and in Serbia (Zubović \& Domazet, 2013). However there is a need to extend the period of observation.

The paper consists of five parts: After the introductory sections, the next part describes methodology used in the paper, while in third and fourth we deliver the results collected form the Serbian labour market. In the last section there is presented the analysis, discussion and conclusions on the findings.

\section{Methodology}

Methodology in this paper relies on large sets of data. For the comparative purposes, the unemployment data from EU countries was collected from secondary source of Eurostat, and for Serbia from the Statistical Office of Serbia.

For the purpose of conducting a quasi-experiment in this paper there was created a large set of data from National employment service on the persons being registered as unemployed at the times of observation.

The basic premise in the evaluation was that the samples of the target group (persons who participated in ALMP), and the control group of people with whom we compare the variables before exposure to the treatment are assigned to relevant groups at random. This means that the evaluation is conducted for post-formed group of persons, by comparing the results to a group of users achieved after leaving the treatment with the results achieved by the group of the unemployed, who had equal opportunity to be selected in a sample of users, but did not participate in the implementation of active measures. In the comparison there has been used the matched-pair design, as suggested by David (1988) and Luna and Johansson (2007). Thus, the average effect of active measures is defined as the difference between the employment rates of the two groups of people. In accordance to Ognjenović (2007) and Zubović \& Domazet (2013) in research was applied the nearest neighbour matching methodology which has shown the best results in previous researches.

As noted, the sample in our research consist of two groups of individuals (experimental and control group), which were compared over five observable variables (gender, region, education, age, occupation) prior to taking part in 
the treatment in two time periods in 2011 and 2012. In both observations there were large samples with 17943 and 42433 participants. Effectiveness of the measure was made based on the results of comparison of achieved results measured in the period of 6 months after the exit from the measure. Data from National employment service in Serbia, which is connected to database of the Institute of Social Insurance, provided opportunity of tracing and distributing all persons from experimental and control group into 21 divisions as in NACE rev. 2 classification. Classification of different ALMP has been redistributed according to Zubović \& Domazet (2013) into a comparable distribution accepted worldwide.

\section{Data and descriptive statistics}

It is necessary to note that expenditure on ALMP in Serbia as a share of GDP is still trailing behind EU average, as well as behind all EU transitional countries, except for Bulgaria (Table 1).

Table 1. ALMP financing in EU as a share of GDP (2008-2011)

\begin{tabular}{|c|c|c|c|c|}
\hline GEO/TIME & 2008 & 2009 & 2010 & 2011 \\
\hline EU 27 & 0.466 & 0.536 & $\mathrm{n} / \mathrm{a}$ & $\mathrm{n} / \mathrm{a}$ \\
\hline EU 15 & 0.484 & 0.554 & $\mathrm{n} / \mathrm{a}$ & $\mathrm{n} / \mathrm{a}$ \\
\hline EU 10 (transition countries) $^{*}$ & 0.161 & 0.232 & 0.298 & $0.216^{1}$ \\
\hline Bulgaria & 0.253 & 0.224 & 0.094 & 0.133 \\
\hline Czech Republic & 0.152 & 0.169 & 0.221 & 0.178 \\
\hline Estonia & 0.035 & 0.149 & 0.142 & 0.148 \\
\hline Latvia & 0.078 & 0.272 & 0.513 & 0.334 \\
\hline Lithuania & 0.139 & 0.200 & 0,226 & 0.183 \\
\hline Hungary & 0.185 & 0.358 & 0.527 & 0.347 \\
\hline Poland & 0.468 & 0.526 & 0.602 & 0,343 \\
\hline Romania & 0.060 & 0.041 & 0.029 & 0.020 \\
\hline Slovenia & 0.093 & 0.230 & 0.401 & 0.255 \\
\hline Slovakia & 0.150 & 0.150 & 0.233 & 0,223 \\
\hline SERBIA & 0.110 & 0.120 & 0.120 & $0.170^{* *}$ \\
\hline
\end{tabular}

Source: Author 
Despite the efforts made before 2011, when the government was following its plan to increase expenditure on ALMP to $0.4 \%$ until 2015, that year was the latest with an increase in spending.

If we take historical data in Serbia on the size of the expenditure on ALMP, we may see that except for the year 2011, there was stagnation or reduction in total amounts (Table 2). In 2012, as marked in introductory section, as a result of the need for decrease in government spending, expenditure on ALMP was more than halved.

Table 2. ALMP financing in Serbia in nominal values and as a share of GDP (2008-2012)

\begin{tabular}{|c|c|c|}
\hline Years & Expenditure (mil $€$ ) & \% of share in GDP \\
\hline 2008 & 34.64 & $0,11 \%$ \\
\hline 2009 & 36.84 & $0,12 \%$ \\
\hline 2010 & 36.63 & $0,12 \%$ \\
\hline 2011 & 55.50 & $0,17 \%$ \\
\hline 2012 & 20.08 & $0,07 \%$ \\
\hline \multicolumn{2}{|c|}{} \\
\hline
\end{tabular}

Source: Author

For that purpose research in this paper there has been made by the means of conducting a quasi-experiment in two different time periods, namely 2011 and 2012 , in order to provide insight on the possible difference in effects of ALMP while changing total amounts spent. The results from the first observation in 2011 have been presented in research conducted by Zubović and Domazet (2013). As compared to the research on 2011 data, in which there were 768,311 registered persons at National employment agency (NES) which represented the research population, in 2012 there were in total 827,840 such persons. Out of total population, young persons, whom we specifically looked upon in this research have accounted for 112.874 positions at NEA, which will be presented later on in this paper.

In table 3, one may find historical data for the period 2008-2012 which includes distribution of persons registered at NEA at the beginning of respective year, by (non)participation in different types of treatment conducted during the year. 
Zubović J., Nikolić I: Determining the Effectiveness of ALMP on Youth in Serbia

Table 3. Participation of registered unemployed persons in ALMP in Serbia (2008-2012)

\begin{tabular}{|c|c|c|c|c|c|c|}
\hline $\begin{array}{l}\text { ALMP } \\
\text { Code }\end{array}$ & ALMP Measures ${ }^{\star *}$ & 2008 & 2009 & 2010 & 2011 & 2012 \\
\hline & No treatment & 825,956 & 767,277 & 794,016 & 768,311 & 810,395 \\
\hline $2-7$ & With treatment & 24,438 & 27,241 & 23,262 & 29,798 & 17,445 \\
\hline $2.1-2.3$ & Training & 1,851 & 2,699 & 4,312 & 3,596 & 3,698 \\
\hline 2.4 & $\begin{array}{l}\text { Apprenticeship Train- } \\
\text { ing }\end{array}$ & 2,963 & 7,773 & 5,706 & 9,870 & 3,288 \\
\hline 3 & $\begin{array}{l}\text { Job rotation and job } \\
\text { sharing }\end{array}$ & 0 & 0 & 0 & 0 & 0 \\
\hline 4 & $\begin{array}{l}\text { Employment incen- } \\
\text { tives }\end{array}$ & 12,482 & 7,309 & 6,486 & 7,138 & 3,288 \\
\hline 5 & $\begin{array}{l}\text { Supported employ- } \\
\text { ment }\end{array}$ & 0 & 40 & 858 & 1,585 & 1,660 \\
\hline 6 & Direct job creation & 3,854 & 6,150 & 3,471 & 4,034 & 3,244 \\
\hline 7 & Start-up incentives & 2,701 & 2,967 & 2,236 & 3,275 & 2,016 \\
\hline & Combined $^{*}$ & 587 & 303 & 193 & 300 & 253 \\
\hline & Total ${ }^{\star \star \star}$ & 850,394 & 794,518 & 817,278 & 798,109 & 827,840 \\
\hline
\end{tabular}

Source: Author

Here we may note that until 2011 there was no significant fluctuation in share of participation in ALMP, but in 2012, there was a significant decrease, which is the result of cut in government expenditures. It is easily evident that largest decrease was in both types of incentives and especially in in apprenticeship training. That will provide opportunity to find out whether such changes have affected the overall effectiveness of ALMP.

\section{Results and discussion}

National employment agency in Serbia has made remarkable progress in its efforts to upgrade its databases, statistical potential and linkage of its data to other databases in Serbia, like the Institute for social insurance. Such technological advances provided better information on employment, and facilitated tracing a person after leaving unemployment register, on the basis of person's unique number. With a help of such tool we have prepared detailed data set on the employability of persons who have been registered at NEA at the beginning of the experiment (table 4). 
Zubović J, Nikolić I.: Determining the Effectiveness of ALMP on Youth in Serbia

Table 4. Number of persons and length of employment of persons from NES register in Serbia

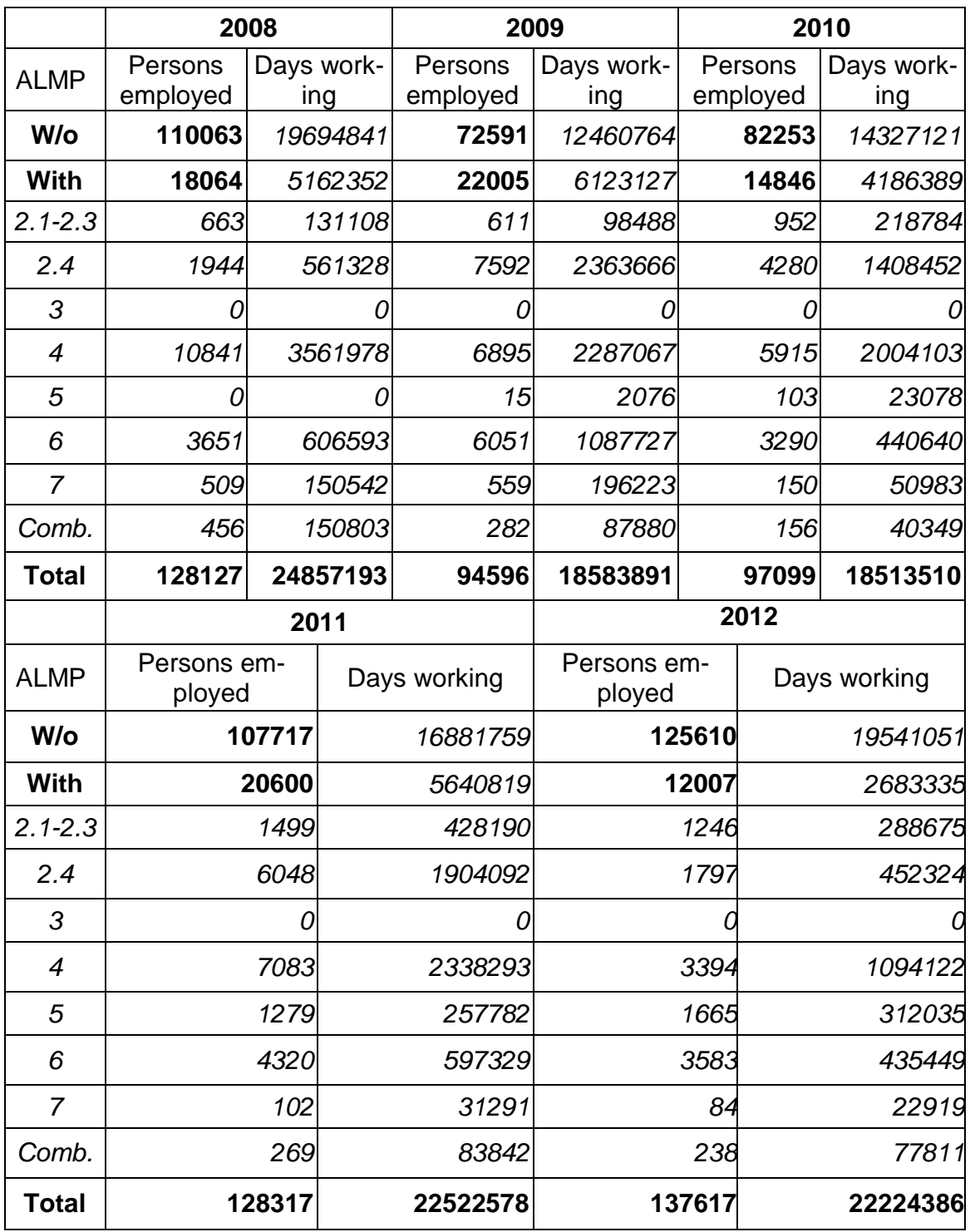

Source: Author

In preparing table 4 at first there has been collected information on employment of people from the sample in two fold manner. For those who have not 
participated in any LMP measure there has been looked the number of them who have been employed during respective year and for the number of days that they worked. For persons who have entered into any LMP measure, information was collected on the number of people and days that they had been working in the period of 12 months after exit from the treatment.

Combining the data with those presented in table 3 , one may find in table 4 additional information on how many persons (from the total population among different groups, according to whether persons has taken part, and in which type of ALMP) and how many days have they been employed during the period of 12 months after January 1st or after exiting from treatment.

It is evident that significantly larger portion of persons who have been participating in any treatment have had opportunity to gain a job, ranging between $50 \%$ and $84 \%$ depending on the year. At the same time only between $9 \%$ and $15 \%$ of those who haven't participated in treatments have found jobs. However this comparison is misleading for number of reasons, among which the most important one is the inequality of the samples' members.

Therefore it was necessary to apply matching model as described in methodological section, in order to get precise information on how effective some of the measures was. The pairs were matched from the control and experimental group according to the variables listed in table 5.

Table 5. Matching pairs of experimental group to control group

\begin{tabular}{|c|l|c|c|c|}
\hline Rank & Variable & $\begin{array}{c}\text { Number of cate- } \\
\text { gories }\end{array}$ & $\begin{array}{c}\text { Matching share } \\
\text { (in \%) }\end{array}$ & $\begin{array}{c}\text { Mismatching } \\
\text { (in units) }\end{array}$ \\
\hline $\mathbf{1}$ & Gender & 2 & $100 \%$ & 0 \\
\hline $\mathbf{2}$ & Region & 30 & $100 \%$ & 0 \\
\hline $\mathbf{3}$ & Education & 10 & $99.86 \%$ & 61 \\
\hline $\mathbf{4}$ & Age & 10 & $100 \%$ & 0 \\
\hline $\mathbf{5}$ & Occupation & 19 & $96.97 \%$ & 1284 \\
\hline & All five & & $96.83 \%$ & 1345 \\
\hline
\end{tabular}

Source: Author

Since the samples are very large, it was to expect that there would be some mismatching among pairs. However, total mismatching is just above $3 \%$, which is statistically insignificant, so that we may deduce that the results that we have found are reliable. 
By applying the matched paired design methodology on two samples, there have been obtained precise results what share of total time (6 months) the persons belonging to each group have been working. Data for 2011 have been taken from research conducted by Zubović \& Domazet (2013), as long as data from 2012 are added in current research.

Table 6. The results of MPD test (2011-2012)

\begin{tabular}{|c|c|c|c|c|c|}
\hline \multirow{3}{*}{$\begin{array}{l}\text { ALMP } \\
\text { code }\end{array}$} & \multirow{3}{*}{ Group } & \multicolumn{4}{|c|}{6 months after exit (\% time) } \\
\hline & & \multicolumn{2}{|c|}{ Jan-June 2011} & \multicolumn{2}{|c|}{ Jan-Dec 2012} \\
\hline & & Employed & Unemployed & Employed & Unemployed \\
\hline \multirow{2}{*}{ 2.1-2.3 } & experimental & $55,2 \%$ & $44,8 \%$ & $49,9 \%$ & $50,1 \%$ \\
\hline & control & $14,2 \%$ & $85,8 \%$ & $18,7 \%$ & $81,3 \%$ \\
\hline \multirow{2}{*}{2.4} & experimental & $70,7 \%$ & $29,3 \%$ & $58,4 \%$ & $41,6 \%$ \\
\hline & control & $16,2 \%$ & $83,8 \%$ & $45,3 \%$ & $54,7 \%$ \\
\hline \multirow{2}{*}{3} & experimental & - & - & - & - \\
\hline & control & - & - & - & - \\
\hline \multirow{2}{*}{4} & experimental & $78,9 \%$ & $21,1 \%$ & $83,0 \%$ & $17,0 \%$ \\
\hline & control & $31,4 \%$ & $68,6 \%$ & $37,7 \%$ & $62,3 \%$ \\
\hline \multirow{2}{*}{5} & experimental & $21,1 \%$ & $78,9 \%$ & $27,7 \%$ & $72,3 \%$ \\
\hline & control & $15,6 \%$ & $84,4 \%$ & $22,8 \%$ & $77,2 \%$ \\
\hline \multirow{2}{*}{6} & experimental & $29,6 \%$ & $70,4 \%$ & $16,0 \%$ & $84,0 \%$ \\
\hline & control & $0,0 \%$ & $100,0 \%$ & $21,0 \%$ & $79,0 \%$ \\
\hline \multirow{2}{*}{7} & experimental & $78,6 \%$ & $21,4 \%$ & $82,2 \%$ & $17,8 \%$ \\
\hline & control & $26,2 \%$ & $73,8 \%$ & $25,0 \%$ & $75,0 \%$ \\
\hline \multirow{2}{*}{ Total } & experimental & $40,2 \%$ & $59,8 \%$ & $62,6 \%$ & $37,4 \%$ \\
\hline & control & $23,7 \%$ & $76,3 \%$ & $34,1 \%$ & $65,9 \%$ \\
\hline
\end{tabular}

Source: Author

From table 6 we may see that there are large differences in the effects among different types of measures. In average participants in treatments have around $28 \%$ higher chance to remain employed 6 months later as compared with non-participants. As expected, the employment incentives are delivering best results. However, these measures are very expensive, and in the long 
Zubović J., Nikolić I: Determining the Effectiveness of ALMP on Youth in Serbia

term may not be cost effective. Similar explanation may be given for start-up incentives.

Finally, after the structure had been set up, we were able to focus on youth population. In table 7 one may see the comparative results of general vs. youth population in two different years, both for experimental and for the control group.

Table 7. The results of MPD on youth population (experimental vs. control group)

\begin{tabular}{|c|c|c|c|c|c|c|}
\hline \multirow{2}{*}{$\begin{array}{l}\text { ALMP } \\
\text { code }\end{array}$} & \multirow{2}{*}{ ALMP Measures } & \multirow{2}{*}{ Gr. } & \multicolumn{2}{|c|}{ Jan-June 2011} & \multicolumn{2}{|c|}{ Jan-Dec 2012} \\
\hline & & & Total & Youth & Total & Youth \\
\hline \multirow{2}{*}{ 2.1-2.3 } & \multirow{2}{*}{ Training } & E & $55,2 \%$ & $55,0 \%$ & $49,9 \%$ & $37,9 \%$ \\
\hline & & $\mathrm{C}$ & $14,2 \%$ & $17,1 \%$ & $18,7 \%$ & $15,7 \%$ \\
\hline \multirow{2}{*}{2.4} & \multirow{2}{*}{$\begin{array}{l}\text { Apprenticeship train- } \\
\text { ing }\end{array}$} & $E$ & $70,7 \%$ & $68,4 \%$ & $58,4 \%$ & $58,9 \%$ \\
\hline & & $C$ & $16,2 \%$ & $13,0 \%$ & $45,3 \%$ & $27,5 \%$ \\
\hline \multirow{2}{*}{3} & \multirow{2}{*}{$\begin{array}{l}\text { Job rotation and job } \\
\text { sharing }\end{array}$} & $E$ & - & - & - & \\
\hline & & C & - & - & - & \\
\hline \multirow{2}{*}{4} & \multirow{2}{*}{$\begin{array}{l}\text { Employment incen- } \\
\text { tives }\end{array}$} & $\mathrm{E}$ & $78,9 \%$ & $70,8 \%$ & $83,0 \%$ & $88,0 \%$ \\
\hline & & C & $31,4 \%$ & $38,2 \%$ & $37,7 \%$ & $48,5 \%$ \\
\hline \multirow{2}{*}{5} & \multirow{2}{*}{$\begin{array}{l}\text { Supported employ- } \\
\text { ment and rehabilita- } \\
\text { tion }\end{array}$} & $E$ & $21,1 \%$ & $22,0 \%$ & $27,7 \%$ & $24,8 \%$ \\
\hline & & C & $15,6 \%$ & $13,9 \%$ & $22,8 \%$ & $19,3 \%$ \\
\hline \multirow{2}{*}{6} & \multirow{2}{*}{ Public works } & $E$ & $29,6 \%$ & $10,2 \%$ & $16,0 \%$ & $17,5 \%$ \\
\hline & & C & $0,0 \%$ & $0,0 \%$ & $21,0 \%$ & $13,1 \%$ \\
\hline \multirow{2}{*}{7} & \multirow{2}{*}{ Start-up incentives } & $E$ & $78,6 \%$ & $81,8 \%$ & $82,2 \%$ & $82,3 \%$ \\
\hline & & C & $26,2 \%$ & $26,8 \%$ & $25,0 \%$ & $28,8 \%$ \\
\hline \multirow{2}{*}{ Total } & & E & $40,2 \%$ & $47,6 \%$ & $62,6 \%$ & $62,8 \%$ \\
\hline & & C & $23,7 \%$ & $23,1 \%$ & $34,1 \%$ & $36,6 \%$ \\
\hline
\end{tabular}

Source: Author

From table 7 one may observe that there are some differences among youth population as compared to general. First of all training seems to be less effective in youth cohort. The difference is more enhanced in the second observed year. That may be explained by the fact that youth population in average are more educated than older, meaning that they already have previously obtained knowledge being offered. Effectiveness of apprenticeship training has been declining as well, but at the slower pace for youth population. Employment incentives are most effective for youth. Their effectiveness has grown significantly since the previous observation. Public works are showing the worst results. It is noticeable that there might even be negative effects for 
participants. That may be explained by the fact that public works are limited to 3 months periods, and that persons taking part, after the exit from the measure, are not really working for jobs until new public call is opened.

\section{Conclusions}

The unemployment in Serbia is very high and it is continuously growing since 2008. The active labour market policies alone cannot solve the problem of high unemployment - they need to be part of a comprehensive strategy to tackle unemployment, especially in the times when there is high pressure on governments to reduce public spending.

Results of two year empirical research in Serbia show positive results, indicating that especially in the period of crisis when there is very low number of job vacancies, active measures can significantly improve labour market conditions. The results are not very different for youth cohort in the labour market. Some policies are bringing weaker returns, and some are showing good prospects, but in average there is only small difference as compared to general population. What is very surprising is that despite reduced expenditure on ALMP, their effectiveness is growing. However that growth is not as rapid for youth as it is for other participants, but it is still higher by $15 \%$ than in the previous year.

There are major differences in achieved effectiveness among treatments: Poor results, with control group performing better than experimental are shown in Public Works. At the same time very good results are experienced in Employment incentives and Startup-incentives.

Finally it is to say that it might be necessary to conduct another testing for 2013, in order to confirm the trends. All this findings may be very important for policy makers, since it is obvious that reduced funding does not necessarily result in reduced effectiveness.

\section{References}

Ognjenović, K. (2007). Evaluacija aktivnih mera na tržištu rada Srbije primenom metoda sklonosti ka učešću u tretmanu. Ekonomski anali, 52(172), 21-53.

David, H.A. (1988). The Method of Paired Comparisons. New York: Oxford University Press

EUNES (2011) Evaluacija neto efekata aktivnih mera tržišta rada, EUNES IPA Project 2008, Belgrade, available on http://www.eunesproject.eu/documents/Evaluacija neto efekata AMTR.pdf 
Zubović J., Nikolić I: Determining the Effectiveness of ALMP on Youth in Serbia

de Luna, X. \& and Johansson, P. (2007) Matching estimators for the effect of a treatment on survival times, IFAU Working paper2007:1, Uppsala.

Matkovic, T, Babic, Z, Vuga, A (2012) Evaluation of Active Labour Market Policies in 2009 and 2010 in the Republic of Croatia, Revija za socijalnu politiku, vol 19, issue 3, pp 303-336, DOI: 10.3935/rsp.v19i3.1100

National Bank of Serbia (2013) Serbian Debt Analysis, available on http://www.nbs.rs/export/sites/default/internet/latinica/90/dug/dug | 2013 .pdf

Sredojević Z, Jeločnik M, Subić J (2011): Economic indicators of condition and tendencies of Serbian economy, Economia - Seria Management, Volume 14, Issue 2, pp. 348-358, ISSN 1454-0320

Statistical Office of the Republic of Serbia (2013) Labour force survey, available on

http://webrzs.stat.gov.rs/WebSite/repository/documents/00/00/96/02/SB 564 ARS 2012+sajt.pdf

Zubović J, Subić J (2011) Reviewing Development of ALMP and the Evaluation Techniques in ed. Andrei et al. The Role of Labour Markets and Human Capital in the Unstable Environment, Karta Graphic, Ploiesti, Romania

Zubović, J \& Domazet, I (2013): Effectiveness of government interventions at labour markets: the case of women and youth in Serbia. Actual Problems of Economics , Vol. 13, No. 139 (15. January 2013): pp. 302-313. 